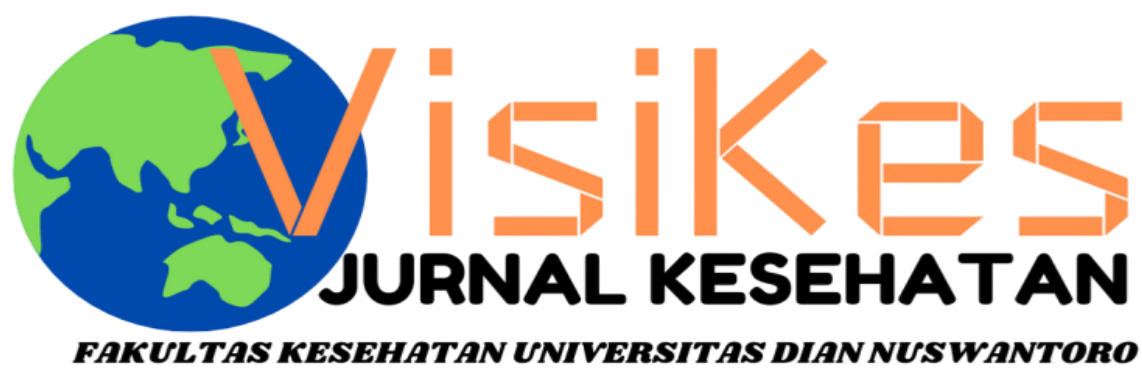

ISSN 1412-3746

FAKULTAS KESEHATAN UNIVERSITAS DIAN NUSWANTORO

Persepsi Mahasiswa Keperawatan Tentang Eskalasi Tenaga Perawat

Rendi Ariyanto Sinanto', Vivi Retno Intening ${ }^{2}$

Risiko kesehatan $\mathrm{Pb}$ dan $\mathrm{Hg}$ pada sayuran di desa Kopeng Kabupaten Semarang

Indira Casheila Anindityo ${ }^{1}$, Nur Endah Wahyuningsih ${ }^{2}$, Yusniar Hanani Darundiati ${ }^{3}$

Analisis Pelaksanaan Program Indonesia Sehat Dengan Pendekatan Keluarga (Pispk) Dalam Capaian Indeks Keluarga

Sehat Di Kabupaten Brebes Tahun 2020 Studi Pada Puskesmas Kluwut Kabupaten Brebes

Rizky Aprilianti Lestari ${ }^{1}$ dr. Antono Suryoputro ${ }^{1}$ Dr. dr. Apoina Kartini. M. Kes ${ }^{1}$

Disiplin Keselamatan dan Kesehatan Kerja melalui pemakaian alat pelindung diri di laboratorium kimia PT Sucofindo

Jakarta

Susan Endah Kartikasari ${ }^{1}$, Tatan Sukwika ${ }^{2}$

Perbedaan Pengetahuan Anemia dan Tablet Tambah Darah (TTD) Sebelum dan Sesudah Pendidikan Kesehatan Melalui

Media Video dan Aplikasi Quizlet

Devita Sari ${ }^{1}$, Gisely Vionalita ${ }^{2}$

Tingkat Pengetahuan Dan Perilaku Mahasiswi Mengenai Legalitas Dan Keamanan Kosmetik

Hani Sri Fitriani, Rizki Siti Nurfitria

Evaluasi Manajemen Dokumen Rekam Medis Di Filing Aktif Rumah Sakit Swasta Kabupaten Semarang

Bobby Anggara Laksana Putra ${ }^{1}$, Retno Astuti Setjaningsih ${ }^{2}$

Tingkat Pengetahuan Gizi Seimbang dan Profil Kesehatan Sopir Bus Antar Kota

Vilda Ana Veria Setyawati ${ }^{1}$, Bayu Yoni Setyo Nugroho ${ }^{1}$

Pengaruh Pengetahuan Dan Motivasi Kerja Terhadap Penerapan Early Warning Score System Di Rsup H Adam Malik Ita Riahna Pinem ${ }^{1}$, Zulfendri', Siti Saidah Nasution ${ }^{3}$

Analisis Penelusuran Masker Sebagai Protokol Kesehatan Saat Pandemi Covid-19 Di Indonesia: Studi Google Trends Ully Febra Kusuma ${ }^{1}$, Nurunnisa Arsyad ${ }^{2}$, Melissa Shalimar Lavinia ${ }^{3}$, Selvia Rahayu ${ }^{4}$, M. Khairul Kahfi , Rizma Adllia Syakurah ${ }^{6}$ Perilaku Hidup Bersih Dan Sehat (Phbs) Dengan Kejadian Sakit Pada Siswa Sekolah Dasar Di Kabupaten Banyumas Windri Lesmana Rubai ${ }^{1}$, Pramesthi Widya Hapsari', Katri Andirini Surijati ${ }^{3}$

Identifikasi Risiko Ganguan Muskuloskletal Pada Pekerja Percetakan Dengan Metode Nordic Body Map

Octavianus Hutapea ${ }^{1}$, Moch.Sahri', Rustam Basuki ${ }^{3}$

Literatur review: Implementasi Bauran Pemasaran 7P Terhadap Tingkat Kepuasan Pasien Di Rumah Sakit

Desi Natalia Marpaung ${ }^{1}$ Ernawaty $^{2}$ Diansanto Prayoga ${ }^{3}$ Syifa'ul Lailiyah $^{4}$

Kelengkapan Informasi Medis Untuk Mendukung Kodefikasi Penyakit Jantung Guna Mewujudkan Kualitas Data Informasi Medis Di Rumah Sakit Islam Sultan Agung Semarang

Dyah Ernawati ${ }^{1}$, Ratna Rifatul Ulya ${ }^{2}$, Arif Kurniadi ${ }^{3}$

Kajian Faktor Kendala Dokter Tidak Menggunakan Aplikasi Wifi Tb Di Kota Semarang

Arif Kurniadi', Evina Widianawati2, Dyah Ernawati ${ }^{3}$

Analisis Pelaksanaan Program Penanggulangan Tuberkulosis Paru Di Puskesmas Purwoyoso Kota Semarang

Nahari Ratu Cempaka Wilis ${ }^{1}$ Hardi Warsono ${ }^{2}$ M. Sakundarno Adi ${ }^{3}$

Hubungan Penggunaan Alat Pelindung Diri (Apd) Dengan Kadar Sgot Dan Sgpt Dalam Darah Pada Petani Padi

Iga Maliga, Rafi'ah

Faktor Risiko Kejadian Stunting Pada Balita di Wilayah Kerja Puskesmas Pandan Kabupaten Sintang

${ }^{1}$ Agustini Elisabet, ${ }^{2}$ Elvi Juliansyah

Peran Suami Dan Petugas Kesehatan Dengan Deteksi Dini Kanker Serviks

Christina Leasa, ${ }^{1}$ Mariene Wiwin Dolang

Analisis Penerapan Protokol Kesehatan terhadap Tingkat Kepatuhan Pada Pekerja informal Selama Pandemi Covid-19

MG Catur Yuantari ${ }^{1}$, Enny Rachmani ${ }^{2}$, Eti Rimawati ${ }^{1}$, Sri Handayani ${ }^{1}$, Edi Jaya Kusuma ${ }^{2}$

Peran Pengawas Minum Obat Dan Pendampingan Berobat Ulang Dengan Keberhasilan Pengobatan Tb Paru

Taswin $^{\left.1^{*}\right)}$, (zan $^{1)}$, Wahyuddin $^{1)}$, Dahmar ${ }^{1)}$

Faktor Determinan Sosial Dan Gambaran Kejadian Post Traumatic Syndrome Disorder (Ptsd) Pasca Banjir Di Dki Jakarta

Dan Bekasi Tahun 2020

Thresya Febrianti ${ }^{1}$, Nurfadhillah ${ }^{2}$, Mitha Nurhjanah ${ }^{3}$, Tiara Kautsa Aliefya ${ }^{4}$

Perbedaan Pola Makan Pada Balita Stunting Dan Tidak Stunting Di Kecamatan Teon Nila Serua (Tns) Kabupaten Maluku Tengah

Trixie Leunupun ${ }^{1}$, Ani Margawati' ${ }^{2}$ Annastasia Ediati ${ }^{3}$

Gambaran Pengelolaan Rekam Medis Rawat Inap Di Rsud Syekh Yusuf Kab. Gowa Tahun 2019

Zilfadhilah Arranury*, Surahmawati, Muhammad Rusmin, Tri Addya Karini, Dian Rezki Wijaya, Ranti Ekasari, Jihan Sulfitri

Analisis Risiko Kesehatan dalam Pemanfaatan Kemball Limbah Sludge Industri Makanan PT. X

Sri Slamet Mulyati ${ }^{1}$, Fajar Sihite ${ }^{2}$ 


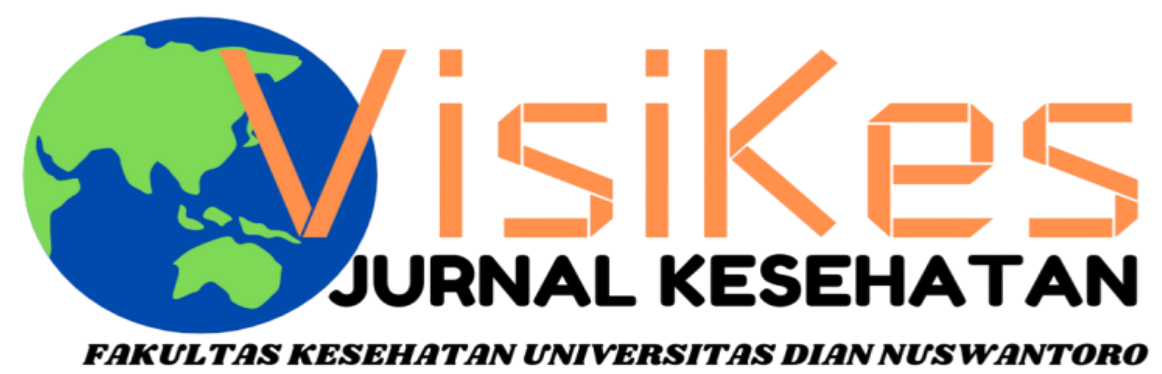

Volume 20, Nomor 1, April 2021

\section{Ketua Redaksi}

Dr. Drs. Slamet Isworo, M.Kes

\section{Penyunting}

Enny Rachmani, SKM, M.Kom, Ph.D

Fitria Wulandari, SKM, M.Kes

\section{Sekretariat}

Lice Sabata, SKM

Desain dan Layout

Puput Nur Fajri, SKM

\section{Alamat Redaksi}

Fakultas Kesehatan Universitas Dian Nuswantoro Jl. Nakula I No. 5-11 Semarang Telp/fax. (024) 3549948

email : visikes@fkes.dinus.ac.id

website $\quad$ : http://publikasi.dinus.ac.id/index.php/visikes/index

VisiKes diterbitkan mulai Maret 2002

Oleh Fakultas Kesehatan Universitas Dian Nuswantoro 


\title{
Perbedaan Pola Makan Pada Balita Stunting Dan Tidak Stunting Di Kecamatan Teon Nila Serua (Tns) Kabupaten Maluku Tengah
}

\author{
Trixie Leunupun ${ }^{1}$, Ani Margawati ${ }^{2}$, Annastasia Ediati $^{3}$ \\ ${ }^{1}$ Magister Ilmu Gizi Fakultas Kedokteran Universitas Diponegoro \\ JI. Prof. Sudarto SH, Tembalang, Semarang, Jawa Tengah 50275, Indonesia \\ ${ }^{2}$ Departemen IImu Gizi Fakultas Kedokteran Universitas Diponegoro \\ Jl. Prof. Sudarto SH, Tembalang, Semarang, Jawa Tengah 50275, Indonesia \\ ${ }^{3}$ Fakultas Psikologi Universitas Diponegoro \\ JI. Prof. Sudarto SH, Tembalang, Semarang, Jawa Tengah 50275, Indonesia \\ email: tleunupun33@gmail.com
}

\begin{abstract}
Stunting is a medical problem, which is a problem of growing process that often occurs to children caused by malnutrition over a long time of period. WHO stated that stunting measurement index can be calculated based on body length compared to age (PB/U) or height compared to age (TB/U). High rate of growth oftenly occurs at the age of toddlers. Nutritional prombel is a health promble that oftenly occurs to toddlers. Insufficient nutrition intake can lead to stunting and can inhibit a growth process to children. Observational analytical research design with case-control design in toddlers aged 2-3 years. The population in this study is all toddlers who live in the working area of Layeni Health Center, TNS District, Central Maluku Regency. The samples in this study were conducted using the Lameshow formula. The study used a ratio of 1:1 so that the total research subjects for the case group were equivalent to the total research subjects for the control group (i.e. 30 children per group), bringing the total number of subjects to 60 children. Analyze the data used to see the differences between variables using the chi-square test. Dependent variables of stunting events and independent variables of diet. The results of the test using chi-square test showed no difference between diet (energy adequacy and protein level) in toddlers who experienced stunting and did not experience stunting where the value $(p>0.05)$. The conclusion of the diet (the level of energy adequacy and protein) respectively in the case group was not very significant differences. But in the control group more toddlers with good levels of energy and protein adequacy.
\end{abstract}

Keywords: toddler, diet, stunting

\begin{abstract}
ABSTRAK
Stunting adalah masalah kesehatan, yang menghambat proses pertumbuhan dan sering terjadi pada anak-anak yang disebabkan oleh kekurangan gizi dalam jangka waktu yang lama. WHO menyatakan indeks pengukuran stunting dapat dihitung berdasarkan panjang badan dibandingkan usia $(\mathrm{PB} / \mathrm{U})$ atau tinggi badan dibandingkan usia (TB/U). Tingkat pertumbuhan yang tinggi sering terjadi pada usia balita. Masalah gizi adalah Masalah kesehatan yang sering terjadi pada balita. Asupan gizi yang tidak mencukupi dapat menyebabkan stunting dan dapat menghambat proses pertumbuhan pada anak-anak. Desain penelitian analitik observasional dengan desain case-control pada balita berusia 2-3 tahun. Populasi dalam penelitian ini adalah seluruh balita yang tinggal di wilayah kerja Puskesmas Layeni, Kecamatan TNS, Kabupaten Maluku Tengah. Sampel dalam penelitian ini dilakukan menggunakan rumus Lameshow. Penelitian ini menggunakan rasio 1:1 sehingga total subjek penelitian untuk kelompok kasus setara dengan total subjek penelitian untuk kelompok kontrol (yaitu 30 anak per kelompok), sehingga jumlah total subjek menjadi 60 anak. Analisis data yang digunakan untuk melihat perbedaan antara variabel menggunakan uji chisquare. Variabel dependen adalah stunting dan variabel independen adalah pola makan. Hasil uji menggunakan uji chi-square tidak menunjukkan perbedaan antara pola makan (tingkat kecukupan energi dan protein) pada balita yang mengalami stunting dan tidak mengalami stunting dimana nilainya $(p>0,05)$. Kesimpulan dari pola makan (tingkat kecukupan energi dan protein) masingmasing dalam kelompok kasus tidak terlalu signifikan perbedaan. Tetapi dalam kelompok kontrol lebih banyak balita dengan tingkat kecukupan energi dan protein yang baik.
\end{abstract}

Kata kunci: Balita, pola makan, stunting 


\section{PENDAHULUAN}

Stunting pada masa kanak-kanak merupakan suatu hambatan yang dapat mempengaruhi perkembangan anak. Secara global dapat mempengaruhi kurang lebih 165 juta anak di bawah usia 5 tahun. ${ }^{1}$ Secara nasional, prevalensi balita stunting mengalami penurunan dari tahun sebelumnya yakni $37,2 \%$ di tahun 2013 dan $30,8 \%$ di tahun 2018. ${ }^{2}$ Usia kanak-kanak merupakan usia yang memperlihatkan seorang anak dengan proses tumbuh kembang yang cepat jika dibandingkan saat masih bayi dan juga kebutuhan akan gizi pun meningkat. ${ }^{3}$ Anakanak berusia satu sampai tiga tahun membutuhkan energi sebesar 1350 kkal dan protein sebesar 20 gram sesuai angka kecukupan gizi yang ditetapkan. ${ }^{4}$

Balita yang mengalami kekurangan asupan protein dan energy dapat menyebabkan balita balita tersebut mengalami kegagalan dalam poses pertumbuhannya. Risiko terjadinya stunting pada balita dengan keukupan energi yang redah 9,5 kali lebih besar dari balita dengan tingkat kecukupan energi yang baik. ${ }^{5}$ Sebuah penelitian yang dilakukan di Brazil menyatakan bahwa protein yang dikonsumsi oleh seorang anak harus mencukupi kebutuhan gizi setiap hari. Anak akan berisiko mengalami stunting 1,5 kali lebih besar bila asupan protein yang dikonsumsi berada di bawah kecukupan gizi yang dibutuhkan setiap hari. ${ }^{6}$

Kabupaten Maluku Tengah Provinsi Maluku merupakan salah satu 100 Kabupaten/Kota di Indonesia yang diprioritaskan untuk intervesi stunting. Prevalensi stunting di kabupaten Maluku Tengah untuk setiap tahunnya mengalami peningkatan yang cukup signifikan. Prevalensi stunting pada tahun 2015 sebesar 21,1\%, 2016 sebesar $23,3 \%$ dan tahun 2017 sebesar $32 \%{ }^{7}$ Berbagai upaya melalui program intervensi sudah dilakukan namun stunting tidak menurun tetapi terjadi peningkatan. Hal ini dilihat dari letak geografis Kecamatan TNS yang berada pada dataran tinggi sehingga pola makan pada masyarakat tidak seimbang dengan kebutuhan yang dibutuhkan oleh tubuh. Penelitian sebelumnya menyatakan bahwa pola konsumsi anak yang mengalami stunting tergolong masih kurang terutama pada saat pemberian makanan prelaktal dan ASI eksklusif. ${ }^{8}$ Hasil dari peneitian ini memiliki tujuan untuk melihat apakah terdapat pebedaan pola makan balita stunting dan tidak stunting di Kecamatan TNS Kabupaten Maluku Tengah.

\section{METODE PENELITIAN}

Penelitian analitik observasional dengan desain case control pada balita usia 2-3 tahun. Penelitian ini dilaksanakan pada bulan November 2019. Populasi yang ditetapkan dalam penelitian ini meliputi semua balita yang berdomisili pada wilayah kerja Puskesmas Layeni Kecamatan TNS Kabupaten Maluku Tengah. Penentuan besarnya sampel penelitian dilakukan dengan menggunakan rumus Lameshow. Penelitian ini menggunakan rasio $1: 1$, yaitu jumlah subyek penelitian pada kelompok kasus sama dengan jumlah subyek penelitian pada kelompok kontrol. Dengan demikian jumlah 
kelompok kasus 30 orang dan jumlah kelompok kontrol sebanyak 30 orang, maka jumlah keseluruhan subjek penelitian ini adalah 60 sampel. Variabel independen dalam penelitian ini adalah pola makan balita dan variabel dependen adalah stunting.

Teknik pengumpulan data meliputi data status gizi diukur menggunakan indikator $\mathrm{TB} / \mathrm{U}$ dan BB/U kemudian diinterpretasikan berdasarkan standar antropometri, data pola makan diperoleh dengan menggunakan metode Recall-24 jam setelah itu komposisi bahan makanan dihitung menggunakan nutrisurvey untuk mengetahui banyaknya zat gizi makro yang dikonsumsi kemudian dibandingkan dengan AKG. Analisis data dilakukan terhadap dua variabel yang diduga berhubungan/berkorelasi. Statistik chi-square digunakan sebagai uji untuk membedakan antara dua atau lebih kelompok.

\section{HASIL}

Tabel 1. Karakteristik subjek berdasarkan umur dan jenis kelamin

\begin{tabular}{lcccccc}
\hline Karakteristik Responden & \multicolumn{3}{c}{ Kasus } & \multicolumn{2}{c}{ Kontrol } & \multicolumn{2}{c}{ Jumlah } \\
\cline { 2 - 7 } & $\mathrm{N}$ & $\%$ & $\mathrm{~N}$ & $\%$ & $\mathrm{~N}$ & $\%$ \\
\hline Jenis Kelamin Anak & & & & & & \\
$\quad$ a. Laki-laki & 15 & 50 & 16 & 53,3 & 31 & 51,7 \\
b. Perempuan & 15 & 50 & 14 & 46,7 & 29 & 48,3 \\
\hline Usia Anak & & & & & & \\
a. 2 tahun & 15 & 50 & 21 & 70 & 36 & 60 \\
b. 3 tahun & 15 & 50 & 9 & 30 & 24 & 40 \\
\hline
\end{tabular}

Sebagian besar subyek (53,3\%) adalah merupakan laki-laki yang terdapat pada kelompok kontrol, dan usia terbanyak yaitu usia dua tahun (70\%) juga terdapat pada kelompok kontrol. Dapat disimpulkan bahwa jumlah balita terbanyak yaitu laki laki yang berusia dua tahun terdapat pada kelompok kontrol.

Tabel 2. Tingkat Kecukupan Energi

\begin{tabular}{|c|c|c|c|c|c|c|c|}
\hline \multirow{3}{*}{$\begin{array}{c}\text { Tingkat Kecukupan } \\
\text { Energi }\end{array}$} & \multicolumn{4}{|c|}{ Kelompok } & \multirow{3}{*}{ OR } & \multirow{3}{*}{$\begin{array}{l}\text { Cl } 95 \% \\
\text { UP-LL }\end{array}$} & \multirow{3}{*}{ Nilai $p$} \\
\hline & \multicolumn{2}{|c|}{$\begin{array}{c}\text { Kasus } \\
\text { (Stunting) }\end{array}$} & \multicolumn{2}{|c|}{$\begin{array}{c}\text { Kontrol (non } \\
\text { Stunting) }\end{array}$} & & & \\
\hline & $\mathrm{N}$ & $\%$ & $\mathrm{~N}$ & $\%$ & & & \\
\hline Baik & 14 & 43,8 & 18 & 56,2 & 0,583 & $0,210-$ & 0,438 \\
\hline Kurang & 16 & 57.1 & 12 & 42,9 & & 1,624 & \\
\hline
\end{tabular}

Tabel 2 menunjukan bahwa proporsi anak dengan tingkat kecukupan energi yang baik lebih banyak pada kelompok kontrol $(56,2 \%)$ daripada kelompok kasus $(43,8 \%)$.

Berdasarkan hasil uji chi-square
memperlihatkan tidak ada perbebeda tingkat kecukupan energi balita stunting dan tidak stunting $(p>0,05)$. 
Tabel 3. Tingkat Kecukupan Protein

\begin{tabular}{|c|c|c|c|c|c|c|c|}
\hline \multirow{3}{*}{$\begin{array}{c}\text { Tingkat Kecukupan } \\
\text { Protein }\end{array}$} & \multicolumn{4}{|c|}{ Kelompok } & \multirow{3}{*}{ OR } & \multirow{3}{*}{$\begin{array}{l}\text { CI 95\% } \\
\text { UP-LL }\end{array}$} & \multirow{3}{*}{$\begin{array}{c}\text { Nilai } \\
\mathrm{p}\end{array}$} \\
\hline & \multicolumn{2}{|c|}{$\begin{array}{c}\text { Kasus } \\
\text { (Stunting) }\end{array}$} & \multicolumn{2}{|c|}{$\begin{array}{l}\text { Kontrol (non } \\
\text { Stunting) }\end{array}$} & & & \\
\hline & $\mathrm{N}$ & $\%$ & $\mathrm{~N}$ & $\%$ & & & \\
\hline Baik & 14 & 41,2 & 20 & 58,8 & 0,438 & 0,154 & 0,193 \\
\hline Kurang & 16 & 61,5 & 10 & 38,5 & & 1,243 & \\
\hline
\end{tabular}

Tabel 3 menunjukan bahwa proporsi anak dengan tingkat kecukupan protein yang baik lebih banyak pada kelompok kontrol (58,8\%) daripada kelompok kasus $(41,2 \%)$. Berdasarkan hasil uji chi-square memperlihatkan bahwa tidak ada perbeaan tingkat kecukupan protein balita stunting dan tidak stunting $(p>0,05)$.

\section{PEMBAHASAN}

\section{Karakteristik subjek}

Pada penelitian ini subjek penelitian lebih banyak yang berjenis kelamin laki-laki sebesar (53,3\%). Sebuah penelitian yang dilakukan di Ghana menyatakan permasalahan gizi anak perempuan lebih tinggi dibanding pada anak laki-laki. Karena terdapat perbedaan di dalam keluarga terkait dengan pola pengasuhan, pola pemberian makan serta perawatan pada anak laki-laki dibanding anak perempuan. Akibatnya, permasalahan gizi pada anak perempuan lebih tinggi jika dibandingkan dengan permasalahan pada anak laki-laki. ${ }^{9}$

\section{Tingkat Kecukupan Energi}

Tabel 2 menunjukan bahwa balita dengan tingkat kecukupan energi sebagaian besar termasuk dalam kategori baik. Balita dengan tingkat kecukupan energi yang baik sebanyak (56,2\%). Proporsi balita dengan tingkat kecukupan energi yang baik lebih banyak terdapat pada kelompok kontrol jika dibaningkan dengan kelompok kasus. Berdasarkan uji chi-square didapatkan hasil tidak adanya beda tingkat kecukupan energi balita stunting dan tidak stunting ( $p>0,05)$.

Penelitian ini memperlihatkan hasil yang tidak sejalan dengan hasil penelitian dari Damayanti (2016) yang menyebutkan bahwa terdapat perbedaan tingkat konsumsi energi, protein, zink dan zat besi pada balita yang mengalami stunting dan tidak stunting di Kelurahan Keiawan Putih Tambak Surabaya. ${ }^{5}$ Hasil penelitian ini juga sesuai dengan hasil penelitian dari Prakoso yang menyatakan bahwa ada perbedaan antara tingkat konsumsi energi pada balita stunting dan non stunting di Desa Kopen Kecamatan Teras Kabupaten Boyolali. ${ }^{10}$

Rendahnya tingkat konsumsi energi pada balita sangat bepengaruh terhadap fungsi dan perkembangan otak serta berdampak pula terhadap terhambatnya pertumbuhan dan perkembangan kognitif anak. ${ }^{11}$ Hasil penelitian ini sejalan pula dengan hasil penelitian dari Oktarina (2013) yang menyatakan bahwa rendahnya tingkat konsumsi energi pada balita berisiko 1,28 kali lebih besar mengalami stunting jika dibandingkan dengan balita yang mempunyai tingkat kecukupan energi yang cukup. ${ }^{12}$ 


\section{Tingkat Kecukupan Protein}

Tabel 3 menunjukan bahwa sebagian besar balita dengan tingkat protein yang cukup tergolong dalam kategori baik. Balita yang memiliki tingkat kecukupan protein yang baik sebanyak (58,8\%). Jumlah balita dengan tingkat kecukupan protein yang baik lebih banyak terdapat pada kelompok kontrol jika dibandingkan dengan kelompok kasus. Hasil pengujian dengan menggunakan chi-square menunjukan bahwa tidak terdapat perbedaan signifikan antara tingkat kecukupan protein pada balita stunting dan tidak stunting $(p>0,05)$. Hasil penelitian ini sesuai dengan hasil penelitian dari Maradesa (2014) yang menyatakan bahwa tidak ada hubungan yang signifikan antara asupan protein dengan status gizi TB/U. ${ }^{13}$ Zat gizi yang dibutuhkan tubuh untuk proses pertumbuhan, membangun struktur tubuh (otot, kulit dan tulang) serta berperan dalam mengganti jaringan yang rusak salah satunya ialah protein .Protein juga merupakan zat gizi makro yang memilki fungsi sebagai zat pembangun, pemelihara sel dan jaringan tubuh serta dapat membantu dalam proses metabolisme sistem kekebalan tubuh. ${ }^{14}$

\section{KESIMPULAN}

Tingkat kecukupan energi-protein balita stunting dan tidak stunting tidak memperlihatkan perbedaan yang signifikan. Sebagian besar balita dengan tingkat kecukupan energi-protein tergolong dalam kategori baik. Jumlah balita dengan tingkat kecukupan energi-protein yang baik lebih banyak terdapat pada kelompok kontrol jika dibandingkan dengan kelompok kasus.

\section{SARAN}

Kepada masyarakat terutama para ibu hendaknya selalu memantau tumbuh kembang anak sehingga proses pertumbuhan dan perkembangan dapat terjadi dengan optimal. Selain itu juga, ibu harus selalu memperhatikan dan meningkatkan kebutuhan makanan anak dan memastikan bahwa makanan yang dikonsumsi anak mengandung zat gizi yang cukup serta beragam.

\section{DAFTAR PUSTAKA}

1. WHO. World Health Assembly Global Nutrition Targets 2025. Stunting Policy $B r$. 2014. doi:10.1152/ajpendo.00419.2004.

2. Kemenkes RI. Hasil Utama Riset Kesehatan Dasar Tahun 2018. Kementrian Kesehat Republik Indones. 2018:1-100. doi:1 Desember 2013

3. Purwani E, Mariyam. Pola Pemberian Makan Dengan Status Gizi Anak Usia 1 Sampai 5 Tahun Di Kabunan Taman Pemalang. Mei. 2013;1(1):30-36. http://download.portalgaruda.org/article.p hp? article $=98477 \& \mathrm{val}=5091$.

4. Kementerian Kesehatan RI. Peraturan Menteri Kesehatan Republik Indonesia No 28 Tahun 2019. Angka Kecukupan Gizi Yang Dianjurkan Untuk Masy Indones. 2019;4:1-33.

5. Damayanti RA, Muniroh L, Farapti F. Perbedaan Tingkat Kecukupan Zat Gizi Dan Riwayat Pemberian Asi Eksklusif Pada Balita Stunting Dan Non Stunting. Media Gizi Indones. 2017;11(1):61. doi:10.20473/mgi.v11i1.61-69

6. Assis AMO, Prado MS, Barreto ML, et al. 
Childhood stunting in Northeast Brazil:

The role of Schistosoma mansoni infection and inadequate dietary intake. Eur J Clin Nutr. 2004;58(7):1022-1029. doi:10.1038/sj.ejcn.1601926

7. Hasil Pemantauan Status Gizi. Kementerian Kesehatan. 2017.

8. Nadimin N. Pola Makan, Keadaan Kesehatan Dan Suapan Zat Gizi Anak Balita Stunting $\mathrm{Di}$ Moncong Loe Kabupaten Maros Sulawesi Selatan. Media Kesehat Politek Kesehat Makassar. 2018;13(1):48. doi:10.32382/medkes.v13i1.94

9. Eunice A, Sarah D. An Assessment of the Nutritional Status of under Five Children in Four Districts in the Central Region of Ghana. Asian J Agric Rural Dev. 2013;3(11):851-860.

10. Bayu Adi Prakoso. PERBEDAAN TINGKAT KONSUMSI ENERGI, PROTEIN, VITAMIN A DAN PERILAKU KADARZI PADA ANAK BALITA STUNTING DAN NON STUNTING DI DESA KOPEN KECAMATAN TERAS KABUPATEN BOYOLALI. 2015;(2). doi:10.5897/ERR2015

11. Wijayanti S, Nindya TS. Relationship of Kadarzi (Family Conscious Nutrition) Behavior Practice to Nutritional Status of Children Under Five Years in Tulungagung District. Amerta Nutr. 2017;1(4):379-388. doi:10.20473/amnt.v1.i4.2017.378-388

12. Oktarina Z, Sudiarti T. Faktor Risiko Stunting Pada Balita (24-59 Bulan) Di Sumatera. J Gizi dan Pangan.
2014;8(3):177.

doi:10.25182/jgp.2013.8.3.177-180

13. Eirene. Maradesa, Nova H. Kapantow MIP. Hubungan antara asupan energi dan protein dengan status gii anak usia 1 3 tahun di wilayah kerja Puskesmas Walantakan Kecamatan Lawongan. Univ Sam Ratulangi. 2009:49-56. file://C:/Users/User/Downloads/1269525333-1-SM.pdf.

14. Simbolon D, Rizal A. Asupan Zat Gizi Makro dan Mikro terhadap Kejadian Stunting pada Balita. 2018;9(November):444-449. 